\title{
Enhance the Effectiveness of University Ideological and Political Education based on "Internet +"
}

\author{
Zhiping $\mathrm{Du}^{1, \mathrm{a}}$, Yajing $X \mathrm{Xe}^{2, \mathrm{~b}}$ \\ ${ }^{1}$ Shaanxi University of Science \& Technology, Xi'an, Shaanxi, 710021 \\ a email, ${ }^{b}$ email
}

Keywords: Internet +; Ideological and Political Education; Effectiveness

\begin{abstract}
Internet +" concept since the proposed community will be recognized and respected. Ideological and political education as an important sector of college education should be the courage to seize the "Internet +" Time brings opportunity, relying on the Internet for information technology innovation education model to enhance the effectiveness of ideological and political education. From the "Internet + " and the ideological and political effectiveness of the perspective of education, interpretation of the "Internet +" concept transformational impact on the ideological and political education, and analyzes the problems of the how to use the "Internet + " to increase, effectiveness of its made recommendations.
\end{abstract}

\section{Introduction}

With the rapid development of network information technology, applications and scope of the Internet is also expanding, penetrated into all aspects of social life. "Internet + " concept since the two sessions last year, will be in all walks of life set off a wave of reform. "Technological innovation plays a guiding role in the overall innovation," the development of network information technology for the transformation and upgrading of traditional industries added new boosters, but also to higher education as the most important part of the ideological and political education has brought new opportunities. "Internet +" Time has come, how to use the "Internet +" technology to extend the platform ideological and political education to achieve its effectiveness of the breakthrough, become a major issue Campus Ideological Educators solved.

\section{The Interpretation of Ideological and Political Education under Internet +}

"Internet +" concept prototype is put forward in 2012. The fifth Analysis mobile Internet Expo, two sessions in 2015, by the Chairman of the Board Ma Tencent formally proposed the agenda. In the second session of the National People's Congress held in three subsequent meetings, Premier Li Keqiang from the national strategic perspective, proposed the implementation of "Internet + " action plan, marking the "Internet +" era is coming in the "Government Work Report". "Internet +" represents a new economic form, that is, "give full play to the role of the Internet in the integration and optimization of the allocation of social resources, the depth of the innovations of the Internet merged in all areas of economic, social, improving creativity of the whole society and productivity, a more extensive Internet infrastructure and tools to achieve new forms of economic development. "relying on" Internet + ", a new generation of information technology to achieve the integration and penetration of traditional industries, industrial upgrading has injected new vitality.

Effectiveness is a good starting point for the ideological and political education and the destination, "Internet + " to enhance the effectiveness of ideological and political education has added new impetus. "Internet + " integration and ideological and political education, which means that in order to achieve the network infrastructure and tools to drive innovation of ideological and political education model, includes both Internet technologies to transform traditional political theory courses, including the use of the network the values of ideological and political education into the daily lives of students. "Internet + ideological and political education" is the trend of ideological and political education reform, which not only cause innovative teaching techniques, but also bring about changes in educational philosophy. It makes ideological and political education 
shifted from teaching to pay attention to student concerns, to achieve a truly "people-oriented" education. "Internet +" will tear up the traditional ideological and political education "dull", "uninteresting" and other labels, so that ideological and political education more relevant and appealing. Technical characteristics of the network will promote ideological and political education to get the best results, educators call "Internet +" set off a wave of reform and ideological and political education.

\section{Transformational Impact of Internet + on the Ideological and Political Education}

Ideological and political education is one pair of students ideological education, political guidance, discipline ethics training, the nature of its subject that it must keep up the pace, with the spirit of the times and the flavor of the times. Therefore, the content of ideological and political education can not hang materials, scripted, but should continue to adjust and supplement some hot new material in a timely manner into teaching content to go. Internet technology have obvious advantages, not only a wealth of information resources and reserves, and the fast update rate, spread wide, can provide a steady stream of fresh resources for education ideological and political education. Supplementary network resources greatly broadened the horizons of students, teaching guide students on a hot topic online, political news to discuss, not only stimulate students' interest in learning, but also expose students to the forefront of ideas and information to help in the overall development of students.

Science and technology every major breakthrough, will bring about changes in education. Internet technology combined with classroom teaching, ideological and political education innovation provides a new way. "Internet +" era, Mu class, micro-lessons, flipped classroom and other teaching methods increasingly attracted attention, a huge inspiration for the reform and development of traditional universities.

Mu class transliteration from "MOOC", refers to a large-scale open online courses. Mu class is a flexible free online learning, students can choose the world's top university courses to learn lessons by $\mathrm{Mu}$ internet. At the same time, also contributed to the Mu class education for their return to nature, the learners from their own degree of learning, interest in learning as a starting point to learn, making learning from passive to conscious, more in line with the needs of students. Micro lesson, flipped classroom is a new teaching method based on lessons and developed $\mathrm{Mu}, \mathrm{Mu}$ is a lesson mode. Slightly shorter course, within 5-8 minutes were taught by teachers on a theme, to facilitate students to use fragments of time to learn. In the "flipped classroom" knowledge and learning by students in extracurricular watch instructional videos to complete classroom into a FAQ between teachers and students interact place more responsibility teacher is to help students understand the knowledge and guidance students to apply knowledge. In 2014, the university had already started to build their own ideological and political platform Mu class, Peking University, Fudan University and other colleges and universities also have opened the ideological and political education $\mathrm{Mu}$ Course for the "Internet +" Ideological and Political Theory Teaching Methods Creation accumulated valuable experience.

\section{The Problems of Enhancing Effectiveness of Ideological and Political Education under "Internet +"}

Opportunities and challenges. When we "Internet +" will bring technological innovation and cheering, also have to realize that the "Internet + ideological and political education" is not perfect, there are also some impact negative aspects. To achieve "Internet + " ideological and political education to achieve the maximum effectiveness of the background, we must face up to its problems, so as to provide ideas to solve the problem.

Ideological and political theory course is the most important way of ideological and political education, a teacher-centered education Instilling, generally "one to many" form be completed within a fixed time and place. In this mode, flexibility is very limited learning, personalized learning is almost impossible to achieve, is not conducive to the cultivation of students' innovative thinking. However, as the representative to the $\mathrm{Mu}$ class education network to achieve a major 
breakthrough in the Ideological and Political Theory Courses. New interactive online education methods compared with traditional educational methods, classes, and other $\mathrm{Mu}$, a more lively, less restrictions on time and place, content and form are more attractive. Students can choose to study $\mathrm{Mu}$ class platform independent content, the development of personalized learning programs to educational services to students and development needs. Students can also take advantage of the teaching content network platform to achieve deeper learning. As the network is increasingly being recognized educational methods accepted part of university students began the traditional ideological and political education to produce resentment, even advocated completely new type of education to replace the traditional mode of education, to the authority of the traditional ideological and political education of a very great impact.

Network is a borderless information carrier, in this multicultural coexistence. It has a strong interactive, widespread and equitable, and more attractive to young students, making it an important channel of Western non-Marxist ideology invasion. Some Western countries attempting to infiltrate through the network of Western value system, to promote money worship, hedonism and other Western capitalist values, causing college students lack of faith, values confusion. In addition, the online world is also filled with a lot of pornographic, violent, seriously endangering the health of young students. On the other hand, some student overindulgence of the Internet exchanges also affected the healthy development of their physical and mental. Some students use the network as its spiritual sustenance, indulge in online chat, online games, exclusion normal interpersonal activity, causing human indifference, withdrawn, depression and other issues. The role of the network obsession, but also the emergence of self-awareness of student chaos, causing personality lost in the role-playing.

Effectiveness to achieve "Internet + ideological and political education" as required solid technical support, not only requires a lot of physical network devices, but also the Campus Ideological Educators have excellent technical level. At the moment, classes, and other new teaching model $\mathrm{Mu}$ is still in the initial construction period, network teaching platform is not sufficient, in order to fully promote the universal need to invest a lot of manpower, material and financial resources. Meanwhile, the campus network, websites and other red ideological and political education platform inadequate education, lack of technological innovation, there is a single content, interactivity is not strong, and low views, functions can not meet the actual needs of students. Campus network monitoring way behind technological level system management and maintenance staff as a whole is not high, so the campus network security risks and exposures. In the construction of teachers, part of the old concept of Political Teachers, refused to accept the new network teaching mode, the computer operating level is not high, low overall network quality. These have become a constraint "Internet +" an important factor in ideological and political education and integration.

\section{Promotion Strategies of Ideological and Political Education of College under the "Internet +"}

"Internet + " is an opportunity and a challenge. "Standing in the Internet + " era outlet, how to achieve "Internet +" technology into full play, to become one of the major issues to enhance the effectiveness of ideological and political education of highly urgent.

First, improve the ideological and political education worker Apply "Internet +" capability. Ideological and political education workers are the ideological and political education leader, its ability to directly influence the level of the actual effect of education. "Internet + " era, the personal abilities of teachers put forward higher requirements, colleges and universities ideological and political education workers must strengthen their self-cultivation, to improve their level of computer application. First, the ideological and political education workers to new ideas, innovative spirit and the courage to explore and actively take the initiative to the "Internet + " spirit throughout the work itself. In addition, to improve the ideological and political educators use "Internet + " operational capacity, by careful study, to acquire the necessary skills and knowledge of the Internet, can skillfully use microblogging, micro letter, QQ and other communications software to communicate with students, skilled application network collect and process information. At the same time, be 
innovative teaching methods, learn from foreign experience $\mathrm{Mu}$ class, active learning related technologies, the Internet in teaching practice and classroom teaching will combine exploring teaching model adapted to their own circumstances. Finally, universities should focus on training educator mobile Internet-related knowledge, providing teachers growing internet.

Second, enhance college students' network moral quality. Network World cohabitation, students ideology is not mature, easy to lose yourself in front of some wrong ideas. Therefore, in order to play "Internet +" to enhance the quality of ideological and political education of the positive effect, we must strengthen the guidance and education of college students, college students to enhance the use of the network. Universities should be a comprehensive system of college students network moral education and the rule of law, improve the legal concept of university students network, enhance their sense of responsibility and self-discipline, improve security vigilance to cultivate good character and noble sentiments. Urge students to strengthen their self-cultivation, the legitimate use of the network and use the Internet. Not free to spread rumors, do not browse unsafe sites, consciously resisting pornography, violence, reactionary spam. Enhance students' moral standards and media literacy, and strive to create a harmonious and civilized Internet environment.

Thirdly, improve the content of ideological and political education. Content of ideological and political education there are bright spots, there is nothing new, enable students to attract students to truly resonate, winning the effectiveness can be improved. The Internet is a sea of information, but also a treasure trove of educational resources. Optimization and innovation of ideological and political education of contemporary college students, must rely on the power of the network to inject fresh blood. For example, the use of Internet search engines, the instructor can take the initiative to collect and educational content related to the current political, historical documents, images, data, hot comments and other material, and then, after careful screening and choreography, applied to classroom teaching. In the classroom, the teacher can also be a hot topic on the network introduced into teaching, encourage students to think, to discussions, to guide values in exchange interaction. Fi throughout the world, the ideological and political education who use the Internet have access to the latest domestic news and information, in teaching in close connection with the new situation, new changes expand new content, ideological and political education closer to the development of the times, closer to real life, Further students easily accepted.

Fourth, achieve technology integration "Mu-class" model and the traditional classroom. "Mu class" model is an innovative "Internet + " online learning model has its unique advantages, but there are some limitations, in order to completely replace the classroom teaching is not realistic. For now, only the "Mu class" technological superiority with the traditional ideological and political teaching model combines the advantages to fully realize its value. At this stage, the "flipped classroom" for the blended learning model represents the highest degree of social acceptance. In this mode, the students after class to watch Internet video content learning teaching, practice, to achieve the freedom and flexibility to learn. In the classroom, teachers as well as heavy and difficult interpretation of the discussion, Q \& A, and also allows teachers to learn the extent of the students have a certain control, strengthen the students' understanding cognition. Flipped classroom from the student's level of understanding needed to design and classroom teaching, to achieve a completely "student-centered" teaching. Meanwhile, the promotion and application of hybrid teaching model, pay attention to the $\mathrm{Mu}$ class resources to control, to ensure high-quality online video course, excellent. In addition, the education sector to increase investment in the construction of the $\mathrm{Mu}$ class platform to provide more material and technical support to build Mu class platform.

Fifth, expand the carrier of ideological and political education. Network ideological and political propaganda, carry forward the socialist core values important position and must be compacted and consolidated. In practice, we should continue to improve ideological and political education network platform, expanding the ideological and political education carrier. First, the most important is to strengthen the construction of the campus sites, websites and other red official website, constantly improving its capabilities for students, providing convenient life. Construction of this type of site you want to do both fun and authority, while close to student life, to be in the form of colorful, simply avoid boring reasoning education. At the same time, colleges and 
universities should pay attention to strengthening the construction of network communication tools. Use QQ, micro letter, flying letters and other communication tools, group function, the class group moved to virtual network space, teachers and students to build a convenient platform for the establishment of a harmonious relationship between students, teacher-student relationship to create conditions. In addition, become adept at using microblogging "micro-media" power. Perfection official microblogging construction of schools, colleges and timely release through the microblogging hot news, policy and theoretical study relevant information on the hot topic is to initiate discussions and guide public opinion. College ideological and political educators encourage open microblogging and work with their student attention to each other, to interact. Imperceptibly in a positive and healthy value passed to the students to internalize and heart, outside of the line.

Sixth, strengthen the supervision network environment. The famous American futurist Alvin Toffler said: "Who mastered the information, control of the network, will have the whole world." Internet is a special information carrier, filling a variety of both positive and advanced ideas, there are also gray, violence and even reactionary information, we must strengthen supervision and management of the network environment, promote the network according to norms of social order. From the national level, to accelerate the network information security legal system, the development of relevant laws and regulations; to establish a network of community supervision and law enforcement agencies, social order to destroy the network behavior in a timely manner discipline, purify the air network society; to improve the level of network monitoring technology active research and development to protect the network security of computer information technology to provide strong technical support for the effective implementation of the network of social management. Universities baking should strengthen its network security management, improve network information security monitoring mechanism, the network harmful information defense, filtering and monitoring, clean the campus network environment. Students develop a network code of conduct, regulate students' network behavior. The establishment of a strong network firewall, to maximize the network to prevent spam entering the campus. Optimize the network environment to a healthy and active content occupation the network creates a good atmosphere network.

"Internet + ideological and political education" has become a new trend of the times, a trend. Integration of Internet and Ideological and Political Education in ideological and political education to enhance the attractiveness and appeal of reform and innovation of ideological and political education content and methods of creating new conditions and provide new opportunities. In the ideological and political education practice, we should fully understand the important influence of the Internet to enhance the ideological and political education in terms of, seize opportunities and face challenges, make ideological and political education by the "Internet + " of the force to fly higher and more stable farther.

\section{References}

[1] 2015 "Government Work Report" acronyms Comment [EB / OL] (2015-03-11) [2016-3-11] http://www.gov.cn/xinwen/2015-03/11/content_2832629.htm. 